MAREK PAWLICKI

University of Silesia in Katowice

e-mail: marek.pawlicki@us.edu.pl

\title{
Shadows of War and the Nightmare of Memory: Analysing Trauma in William Golding's Pincher Martin
}

\begin{abstract}
The main aim of this article is to analyse the impact of the Second World War on the eponymous protagonist of William Golding's third novel, Pincher Martin. Concentrating on Christopher "Pincher" Martin's disconnected and often chaotic recollections, as well as his attempts to organise them into a coherent narrative, this article argues that his experience of war can be considered in terms of trauma. The article begins with a short overview of critical perspectives on Pincher Martin, and then goes on to analyse in detail chosen passages from this novel, which are discussed in the context of trauma theory, as formulated by Robert Jay Lifton, Cathy Caruth and Susan Brison. While the main focus of the article is memory and its role in the shaping of the protagonist's identity, the discussion also accounts for the complex symbolism of Golding's novel.
\end{abstract}

Keywords: William Golding, Pincher Martin, World War II, trauma

\section{Pincher Martin as a portrait of a traumatised individual}

Pincher Martin (1956), William Golding's third novel, is one of three novels in Golding's oeuvre, alongside Lord of the Flies and Darkness Visible, which explicitly takes up the subject of war and its influence on human psyche. The novel tells the story of a sailor, Christopher "Pincher" Martin who finds himself shipwrecked on a rock in the middle of the Atlantic. He tries to survive despite the dire weather conditions, and, more importantly, his suffering and ensuing agony. Martin's extreme situation is that of a grievously ill person who finds himself in total seclusion. His task is to recreate his sense of identity, which is already shattered by his experience of war and is further endangered by a delusional state of mind that has resulted from extreme exhaustion and numerous injuries. Isolated on the rock, Martin can create his sense of self only on the basis of his thoughts 
and recollections. Disconnected memories offer an insight into his life: we learn about his youth, which he devoted to acting, his decision to join the navy during the Second World War, and the tragic night when their ship was torpedoed by the enemy. After a week on the rock island, Martin yields to his delusional fantasies and, ultimately, dies of exposure. This version of events is, nonetheless, undermined in the last chapter of the novel, which shows a conversation between the two mariners who recovered his body from the sea. One of the sailors argues that he could not have survived the catastrophe of the ship. As he observes in the last sentence of the novel, "He didn't even have time to kick off his seaboots." statement stands in contrast to the events presented in Chapter One, as one of the first things that Martin manages to do after being thrown overboard is to kick off his boots.

Critical interpretations of Pincher Martin have capitalized on Martin's crimes, presenting him as a character whose actions have condemned him to a state of inner torment. In a sense, this comes as no surprise because Golding himself, in his influential reading of the novel, paints a decisively negative picture of his protagonist:

Christopher Hadley Martin had no belief in anything but the importance of his own life, no God. Because he was created in the image of God he had a freedom of choice which he used to centre the world on himself. [...] The greed for life which was the mainspring of his nature forced him to refuse the selfless act of dying. He continued to exist separately in a world composed of his own murderous nature. His drowned body lies rolling in the Atlantic but the ravenous ego invents a rock for him to endure on. ${ }^{2}$

Golding's authoritative interpretation of his novel clearly places Martin's struggle in the realm of the spirit. According to this view, Martin's self-imposed suffering results from the ill use of his freedom, which has led him to turn away from God. Martin is then a cynical egoist, whose "greed for life" has led him to the symbolic gesture of rejecting death as an end to his existence, even if it is capable of bringing him liberation from his suffering. As a result, he finds himself in a purgatory of his own making, in which he is ultimately forced to confront the monstrous prospect of his own extinction.

The majority of Golding's critics have adapted various aspects of his interpretation into their discussions of Pincher Martin, seeing the novel largely as a representation of a posthumous experience, ${ }^{3}$ and concentrating not on Martin's

1 W. Golding, Pincher Martin, London 1974, p. 208.

2 B. Oldsey, S. Weintraub, The Art of William Golding, Bloomington 1965, p. 94.

3 Bernard S. Oldsey and Stanley Weintraub are close to Golding's vision of the novel, seeing the narrated world not as a projection of an expiring mind, but as "Pincher's post mortem experience of himself" (B. Oldsey, S. Weintraub, op. cit., p. 79). The critics view the novel as comprised of two levels, one of which is the realistic description of his struggle with death, while the other is the story of his disembodied ego: "Realistic as is the surface texture of the novel, beneath it is an allegory of purgatorial experience" (ibid., p. 92). A similar view is expressed by Howard S. Babb, who, pointing to the American title of Golding's novel (The Two Deaths of Christopher Martin), argues that Martin creates the narrated world not before, but after his death. Readers may understand the events narrated in the book as experienced by a living person, "[y]et by the end of the book we must regard what has happened to Martin as the projection of a dead man's mind" (H.S. Babb, The Novels of William Golding, 
suffering, but on moral judgments of his actions. Mark Kinkhead-Weekes and Ian Gregor - two of Golding's most influential critics - see Martin's struggle for survival on the rock as "emblematic of a life of ferocious self-concern, the ravening ego refusing the selfless act of dying." "In this light, the last moments of Martin's life - his refusal or inability to meet a peaceful death - are considered to be a consequence of his lifelong egoism and cruelty.

This article is based on the criticism of metaphysically and ethically-oriented approaches to Golding's novel, which, by emphasizing Martin's responsibility for his sinful life and seeing his island as a kind of self-created purgatory, fail to appreciate the full extent of his dramatic situation. What those theories do is de-emphasize Martin's role as a victim both of the physical elements to which he is subject (if the narrated world is a product of his mind then clearly his suffering must be intellectual or spiritual), and - more importantly in the context of this article - of his traumatic memories. An approach which is better suited to capturing the complex situation of Golding's protagonist is one which is not so quick to formulate ethical judgments of Martin's actions as he confronts his own demise. A psychological, rather than an ethically-oriented perspective on Golding's novel would - I believe - enable the readers to distance themselves from the critical orthodoxy set out by Golding and see the novel not as a fable about the corruptibility of one man, but as a consistent and convincing description of a survivor plagued by his traumatic, ${ }^{5}$ near-death experience, in Martin's case, the torpedoing and the sinking of his ship.

It will be argued in this article that the sinking of Martin's ship constitutes a central event in Martin's life, which shapes his whole recollection process by forcing him to reflect on the events in his life marked by the drama of isolation and powerlessness. In this respect, Martin is not unlike survivors of catastrophes, in whom " $[\mathrm{t}]$ he death encounter reopens questions about prior experiences of separation, breakdown, and stasis as well as countervailing struggles towards

Ohio 1970, p. 68). The same argument is raised in an interesting study of Golding's fiction by Virginia Tiger, who adds that "the survival tale is concerned with his life in Purgatory and his reluctance to surrender to his destiny" (V. Tiger, William Golding: The Dark Fields of Discovery, London 1974, p. 111). The contention that Martin's suffering is a metaphysical experience is also shared by Arnold Johnston, who argues that the created world is part of Martin's attempt to fabricate an elaborate lie (the rock on which he is shipwrecked) in order to obscure the truth of death which he has to face. He adds that this tendency is characteristic of "the modern mind [which] has steadily refused to confront the darker side of human experience" (A. Johnston, Of Earth and Darkness: The Novels of William Golding, Columbia 1980, p. 45). Stephen J. Boyd also believes the island to be Martin's invention. Concentrating on his sinful life before the episode on the island, Boyd observes that by inventing the rock, the protagonist brings about "his own damnation to hell" (S.J. Boyd, The Novels of William Golding, New York 1990, p. 55).

4 M. Kinkhead-Weekes, I. Gregor, William Golding: A Critical Study, London 1967, p. 155.

5 I am adopting Cathy Caruth's definition of trauma as "an overwhelming experience of sudden or catastrophic events in which the response to the event occurs in the often delayed, uncontrolled repetitive appearance of hallucinations and other intrusive phenomena" (C. Caruth, Unclaimed Experience: Trauma, Narrative, and History, Baltimore 1996, p. 11). She stresses the belatedness of traumatic recall, as well as its "unassimilated nature" (ibid., p. 4): the fact that such an event remains obscure to the subject and, as a result, "returns to haunt the survivor later on" (ibid., p. 4). 
vitality; reopens questions, in fact, around all of life's beginnings and endings." The two distinct characteristics of survivor experience, one of which is centred upon the past and the other directed towards the future, are clearly visible in the case of Golding's protagonist. Martin is, on the one hand, deeply preoccupied with his past: a solitary individual in the grip of painful recollections. At the same time, he is determined not to be overcome by images of anxiety and terror and resolves to assert a degree of control over his dramatic situation. As will now be shown, his desperate "struggles towards vitality" also involves coping with an overwhelming feeling of guilt connected with the fact that he is the sole survivor of this catastrophe.

\section{Analysing guilt in Pincher Martin}

The central event in Pincher Martin is related towards the end of the novel, in Chapter Twelve, in which Martin is beset by the memory of his ship's catastrophe. As we learn, the moment before their ship is torpedoed, Martin commands that the vessel should abruptly change course:

"Hard a-starboard for Christ’s sake!"

A destroying concussion that had no part in the play. Whiteness rising like a cloud, universe spinning. The shock of a fall somewhere, shattering, mouth filled-and he was fighting in all directions with black impervious water.

His mouth screamed in rage at the whiteness that rose out of the funnel.

"And it was the right bloody order!"

Eaten. ${ }^{7}$

Martin's issuing of this order has been seen as an expression of hatred toward his one-time friend, Nathaniel. ${ }^{8}$ Commenting on this passage, Arnold Johnston underlines the guilt that Martin experiences when reliving this memory: "The guilt Martin feels for this cannot be dispelled by his attempted rationalization: 'And it was the right bloody order!'"9 Indeed, despite his delusional state of mind, Martin finds himself unable to explain away his guilt by arguing that his order was justified in the light of events which, after all, he did not anticipate at the time.

6 R. Lifton, The Broken Connection: On Death and the Continuity of Life, Washington 1979, p. 170.

7 W. Golding, op. cit., p. 186.

8 Mark Kinkhead-Weekes and Ian Gregor describe the order as “attempted murder" (M. Kinkhead-Weekes, I. Gregor, op. cit., p. 129), arguing that it is only in this cruel way that Martin hopes to regain peace of mind. Arnold Johnston writes: "Chris's last order from the bridge, seconds before his ship is struck by the torpedo, is designed to murder Nat, now his shipmate, by throwing him into the sea from his accustomed perch on a rail" (A. Johnston, op. cit., p. 46). Virginia Tiger sees Martin's decision as a sign of his "true criminality": "he decides to effect the drowning of a generous friend whom he has not earlier been able to control by having the ship turn suddenly" (V. Tiger, op. cit., p. 105). Stephen J. Boyd also sees Martin's decision as an act of revenge which he takes on Nathaniel for predicting his early death (S.J. Boyd, op. cit., p. 59).

9 W. Golding, op. cit., p. 46. 
The recollection of the ship's catastrophe comes back to Martin towards the end of the novel. In his growing madness, he creates his own vision of God (perhaps merely his own alter ego), to which he addresses the final account of his life. This dramatic exchange starts by Martin declaring what he believes in ("The thread of my life" ${ }^{10}$ ), and God amplifying this statement by adding that Martin's determination to survive ("At all costs"11) exceeds those of many other people. The decision to make this desire the driving force of his life is presented as unethical, as is suggested by the curt question posed by God:

"I have a right to live if I can!"

"Where is that written?"

"Then nothing is written."

"Consider."

Contrary to God's suggestion that Martin "consider" whether he wants to continue his miserable existence or to accept death, Martin vehemently rejects the prospect of his own demise, raging against death and embracing life, however miserable and guilt-plagued it may be. He then goes on to pose a question which is, in essence, his accusation of God, as Martin sees Him:

"I prefer it [life]. You gave me the power to choose and all my life you led me carefully to this suffering because my choice was my own. Oh yes! I understand the pattern. All my life, whatever I had done I should have found myself in the end on that same bridge, at that same time, giving that same order-the right order, the wrong order. Yet, suppose I climbed away from the cellar over the bodies of used and defeated people, broke them to make steps on the road away from you, why should you torture me? If I ate them, who gave me a mouth?" "There is no answer in your vocabulary."

He squatted back and glared up at the face. He shouted.

"I have considered. I prefer it, pain and all."13

The beginning of this passage, which presents the curt exchanges between Martin and God (or Martin and himself, as it will be argued), makes it clear that his sense of guilt does not only concern his friend Nathaniel, but all those people who lost their lives in the catastrophe ("the bodies of used and defeated people"14). What is more, it seems that his guilt cannot be limited to the actions for which he is directly responsible (such as the attempted murder of his friend Nat), but concerns the very fact of his survival. It is as if Martin was accusing himself of his desire to survive "at all costs," suggesting that there is no moral justification for this motivation.

It is, of course, possible to see Martin's 'crime' - his overpowering desire to live - as an expression of his greed, and this is precisely the meaning it acquires in the interpretative framework Golding proposes. As it was mentioned at the beginning of this article, Golding saw Martin's desire to survive primarily as an expression of greed: "The greed for life which was the mainspring of his nature

\footnotetext{
10 Ibid., p. 196.

11 Ibid.

12 Ibid.

13 Ibid., p. 197.

14 Ibid.
} 
forced him to refuse the selfless act of dying." 15 If we accept Golding's interpretation, then we also have to acknowledge the fact that the argument raised in this passage is true and accurate: Martin is guilty of his greed, which finds its manifestation in such vices as gluttony, lust, and ambition, as well as his excessive desire to survive. The problem with this interpretation is that it is questionable to put all those motivations on the same scale, suggesting that there is a resemblance between such forms of egoism as destructive lust, or overriding ambition (in Martin's case, the plan to become a successful actor at the cost of others) on the one hand, and the desire to survive the war (or indeed any dramatic circumstances) on the other, whether this survival is considered in the spiritual sense (as in Golding's interpretation), or the physical sense. Leon Surette recognizes this problem when he points out that "[t]he sharpest difficulty this novel [Pincher Martin] has for its readers is its requirement that they withdraw their approval from Martin's indomitable struggle to maintain his identity." ${ }^{16}$ Contrary to what Surette argues, it is not the novel that imposes this requirement on the reader, but its interpretation, as proposed by Golding. It is neither necessary nor ethical to consider Martin's struggle for survival, whether it be physical or mental, as an expression of his immorality.

Instead of treating the words of Martin's God as an authoritative commentary on the protagonist's conduct, it is better to view this apparition as a product of Martin's deluded mind - his own distorted alter ego. From this perspective, Martin's desperate monologue is, in fact, a staged dialogue between two voices representing two aspects of his identity: one that is driven by his survival instinct and one that is deeply rooted in his traumatic past, including such feelings as remorse and guilt. In this improvised dialogue between the two distinct selves, Martin tries to justify - unsuccessfully - his overpowering feeling of guilt. This is apparent on a closer analysis of the passage that presents killing in terms of eating ("If I ate them, who gave me a mouth?"17), underlining the Darwinian context of Martin's struggle. It seems that Martin is doing his best to explain and in this way alleviate his feeling of guilt by arguing that since the instinct to survive is rooted in the nature of any living being, no person should be held fully accountable for his acts in such a dramatic situation. In other words, he is trying to argue his way out of his guilt by asserting that his desire to survive - escape the dark cellar of death - is fundamental to his nature as a human being. The curt reply ("There is no answer in your vocabulary" ${ }^{18}$ ) need not necessarily be interpreted as a sign of his moral corruption, but rather as his inability to reconcile the two forces which govern his thoughts: on the one hand, the desperate desire to survive in spite of everything (and everyone); on the other, the sense that this desire is, in itself, evil. Interpreted from this perspective, the whole dialogue can be seen as a powerful expression of an internal conflict, which cannot easily be resolved.

15 B. Oldsey, S. Weintraub, op. cit., p. 94.

16 L. Surette, A Matter of Belief: Pincher Martin's Afterlife, "Twentieth Century Literature" 1994, Vol. 40, No. 2, p. 221.

17 W. Golding, op. cit., p. 197.

18 Ibid. 
The discussion so far has shown that Martin finds himself in the paradoxical position of trying to explain away his guilt by recourse to a way of thinking (life as a struggle for survival) which in itself is partly the source of this guilt. The fact that Martin himself condemns his own desire to survive is best illustrated by the symbolism he uses to illustrate this struggle: at one point he likens himself to a big, white maggot which has gorged itself on weaker maggots, but which is about to perish and be eaten itself. The eating metaphor, based on violent imagery, conveys Martin's guilt, but also the feeling of dread at the idea of approaching death. The second part of this article will focus on Martin's fear of death, which recurs in his discordant and highly symbolic memories and fantasies.

\section{The death imprint in Martin's memories}

Martin's recollection process is chiefly a chaotic one, characterised by his struggle to distance himself from his painful past. This attempt, in turn, leads to what Susan Brison calls the "radical disruption of memory," 19 defined as "a severing of past from present and, typically, an inability to envision a future." ${ }^{20}$ As a result of his trauma, discontinuity is created between his past and present. The present moment, which has no definite time reference, can be compared to an island in time in that it exists in separation both from the past, which Martin is unable and unwilling to narrate, and from the future, which he cannot anticipate.

The disruption of Martin's memories is best illustrated in a passage taken from Chapter Eleven. Having spent several days on his rock, Martin suffers from extreme exhaustion and numerous hallucinations. His struggle to survive on the island not only consists of taking care of his own body, but also involves making sense of the hostile world in which he has found himself. It seems that the task of survival brings tangible results and Martin regains enough self-confidence to assert that by maintaining mental balance, he can also recuperate physically. Nonetheless, the optimistic mood is suddenly interrupted by an event which catches the readers, as well as the protagonist, completely unawares: "Something was taken away. For an instant he felt himself falling; and then there came a gap of darkness in which there was no one." ${ }^{21}$ The two sentences are followed by a spaced line and a new paragraph, which shows Martin slowly regaining his hold on reality. In the passage quoted below, he tries to explain to himself what caused his sudden loss of consciousness:

There was a separation between now, whenever now was, and the instant of terror. The separation enabled him to forget what had caused that terror. The darkness of separation was deeper than that of sleep. It was deeper than any living darkness because time had stopped or come to an end. It was a gap of not-being, a well opening out of the world and now the effort of mere being was so exhausting that he could only lie sideways and live.

19 S. Brison, Trauma Narratives and the Remaking of the Self [in:] Acts of Memory: Cultural Recall in the Present, eds. M. Bal, J. Crewe, L. Spitzer, Hanover 1999, p. 39.

20 Ibid.

21 W. Golding, op. cit., p. 167. 
Presently he thought.

"Then I was dead. That was death. I have been frightened to death. Now the pieces of me have come together and I am just alive."22

Clearly, Martin's recollection is marked by a feeling of terror. While the nature of this dramatic event (or series of events) remains unexplained, the intensity of this experience is conveyed powerfully at the end of the passage, wherein Martin describes his trauma in terms of death, which has shattered his sense of self. The mentioned disjunction between the past and the present, which is an integral part of this experience, could have been part of a defence mechanism, enabling him to distance himself from his memories (as we read in the passage quoted, "The separation enabled him to forget what had caused that terror" ${ }^{23}$ ). Another passage from the same chapter confirms this interpretation by referring to his recollection as "something that must not be remembered." 24 It can be argued that the memory of the event figures in the narrative as a site of absence; in other words, it is that which has to be repressed if Martin is to maintain his precarious mental balance and carry on with the task of "mere being." 25 The temporal disruption is represented in terms of darkness, which, in turn, denotes death - the state of "notbeing." This state is, as we read, outside of the passage of time ("time had stopped or come to an end"26).

The relationship between trauma and the fear of death is one of the key issues Robert Jay Lifton discusses in his psychological study of the way in which death functions in the human imagination. He defines the death imprint - one of the characteristics of traumatic syndrome - as the intrusion of a death-related image, which leads to overpowering feelings of fear and anxiety. In an important passage, he points out that "the death imprint in traumatic syndrome simultaneously includes actual death anxiety (the fear of dying) and anxiety associated with death equivalents (especially having to do with disintegration of the self)."27

Martin's fears of isolation and disintegration are conveyed by the images of the cellar and the rock, which Martin sees as the starting point and the end of his conscious life:

If one went step by step - ignoring the gap of dark and the terror on the lip - back from the rock, through the Navy, the stage, the writing, the university, the school, back to bed under the silent eaves, one went down to the cellar. And the path led back from the cellar to the rock. $^{28}$

That Martin's childhood is an important reference point in his recollection process becomes apparent in Chapter Nine, in which, gripped by sudden panic at the realization of his loneliness, he tells himself: "It's like those nights when I was

22 Ibid., pp. 167-168.

23 Ibid., p. 167.

24 Ibid., p. 172.

25 Ibid., p. 167.

26 Ibid., p. 168.

27 R. Lifton, op. cit., p. 170.

28 W. Golding, op. cit., p. 173. 
a kid, lying awake thinking the darkness would go on for ever. And I couldn't go back to sleep because of the dream of the whatever it was in the cellar coming out of the corner." ${ }^{29}$ The image of the cellar denotes his fear of darkness, helplessness, and approaching danger. Interestingly, the cellar is also the place inhabited by a repulsive and terrifying old woman, who threatens to keep Martin in confinement for the rest of his life. This symbolic representation of death is highly significant insofar as it plays a major role in the interpretation of the penultimate chapter of the novel, in which Martin has a vision of the old woman, who threatens to attack him. Overcome by fever, he mistakes the old woman for the figure of the stone dwarf, ${ }^{30}$ which he has constructed on the island to keep him company. Armed with a knife, he destroys the dreaded figure, but fails to rid himself of his fears:

He shouted at the rocks but the old woman would not appear among them. She had slipped away down to the cellar. Then he glimpsed her lying huddled in the crevice and he struggled up to her. He fell on her and began to slash with his knife while his mouth went on shouting.

"That'll teach you to chase me! That'll teach you to chase me out of the cellar through cars and beds and pubs, you at the back and me running, running after my identity disc all the days of my life! Bleed and die."”1

There is no better scene in Golding's novel to illustrate the drama of Martin's situation. Sensing that he can no longer escape death, he decides to attack her, choosing once again to assert himself by aggression and hatred, rather than to give in to fear and grief. Doing so, he is both a pathetic and a tragic protagonist: a deluded man who is unable to face reality, and a heroic figure trying to confront his nightmares until the very end of his life.

The various, multilayered symbols which embody Martin's fears converge in the penultimate chapter, which describes a tempestuous storm over Martin's imagined island. The central image here is that of the black lightning. This image has its origins in a conversation Martin once had with Nathaniel. In this conversation Nathaniel talks about his concept of heaven: "Take us as we are now and heaven would be sheer negation. Without form and void. You see? A sort of black lightning destroying everything that we call life." ${ }^{\prime 2}$ Although Nathaniel does not specify whom he means by the pronoun we, it is possible that he is referring not so much to himself and Martin as to the war generation. In Nathaniel's understanding, heaven - whichever way it is imagined - is built on a determined and final negation of the corrupted world. The catastrophic dimension of this negation conveys his hope for a kind of radical purgation and absolution, but it also shows his inability - shared perhaps by his generation - to imagine a heaven based on mercy and goodness. Indirectly then the image shows the corruption of Nathaniel's and

29 Ibid., p. 138.

30 Driven by loneliness, Martin constructs a figure resembling a human being from the rocks he finds on the island. He constructs "the stone dwarf" (ibid., p. 79) primarily with the hope of attracting the attention of a passing ship, but it soon becomes clear that the dwarf's role is to be a witness to his suffering.

31 Ibid., p. 193.

32 Ibid., p. 70. 
Christopher's generation, which cannot extricate itself from the violence inherent in their wartime experience.

The lightning is described in the following passage, which closes the penultimate chapter of the novel:

The lightning came forward. Some of the lines pointed to the centre, waiting for the moment when they could pierce it. Others lay against the claws, playing over them, prying for a weakness, wearing them away in a compassion that was timeless and without mercy. ${ }^{33}$

The scene shows the lightning reaching down to Martin, who is lying on his rock unconscious, and touching the very core of his identity, which is Martin's will to survive. The lightning is an allusion - however remote - to Nathaniel's conception of heaven as "pure negation." Nevertheless, the heaven that Martin reaches is not only a negation of the wartime reality, but, more importantly, the negation of his ego, which found its strongest expression in his will to survive. It can be concluded that the last scene of the penultimate chapter presents the protagonist in the role of victim, not only of nature and its elements, but, more importantly, of the traumatic memories that he heroically but unsuccessfully sought to confront.

\section{Conclusion: Martin as a pathetic and a tragic figure}

Most critics point out that Martin's struggle to survive eventually lead to delirious attempts at self-reconstitution, ultimately resulting in his madness. Pointing to the mythological and literary references in the novel, Kevin McCarron argues that what defines Martin's existence on the island is "his own creation of himself as tragic hero." ${ }^{34} \mathrm{He}$ compares himself to Ajax and Prometheus in the hope that this will reinforce his fantasy of heroic survival on the island. Unable to maintain it, "Martin shows characteristic cunning in deciding that he is mad, preferring this to death." 35 Nonetheless, his attempts to impersonate mythological and literary heroes (such as King Lear) fail, and, as a result, he is made to see that, far from being a tragic hero, he is "a dead man who refuses to die." ${ }^{36}$ McCarron's critical perspective is, in many respects, entirely justified. He is right to point out the discrepancy between Martin's fantasy and reality that is strongly accentuated in Golding's novel. A man on the verge of going mad, who reinvents himself as Ajax and Prometheus to the imagined music of Tchaikovsky and Wagner is, no doubt, a ridiculous figure who is unable to confront reality and so escapes into fantasy. Having said this, it is also true to say that the interpretations underlining Martin's madness as a product of self-calculation run the risk of marginalizing, or neglecting altogether, the heroic aspect of his struggle. The complexity of Golding's protagonist is that he is both a pathetic and a heroic figure; in his will to live, he stops

\footnotetext{
33 Ibid., p. 201.

34 K. McCarron, William Golding, Plymouth 1994, p. 16.

35 Ibid.

36 Ibid.
} 
at nothing, but it is this desire to survive that turns him into "a mythic symbol of human endurance." 37

\section{Bibliography}

Allen W., Tradition and Dream: The English and American Novel from the Twenties to Our Time, London 1964.

Babb H.S., The Novels of William Golding, Ohio 1970.

Boyd S.J., The Novels of William Golding, New York 1990.

Brison S., Trauma Narratives and the Remaking of the Self [in:] Acts of Memory: Cultural Recall in the Present, eds. M. Bal, J. Crewe, L. Spitzer, Hanover 1999.

Caruth C., Unclaimed Experience: Trauma, Narrative, and History, Baltimore 1996.

Golding W., Pincher Martin, London 1974.

Johnston A., Of Earth and Darkness: The Novels of William Golding, Columbia 1980.

Kinkhead-Weekes M., Gregor I., William Golding: A Critical Study, London 1967.

Lifton R., The Broken Connection: On Death and the Continuity of Life, Washington 1979.

McCarron K., William Golding, Plymouth 1994.

Oldsey B., Weintraub S., The Art of William Golding, Bloomington 1965.

Surette L., A Matter of Belief: Pincher Martin's Afterlife, "Twentieth Century Literature" 1994, Vol. 40, No. 2, pp. 205-225, www.jstor.org (access: 15.09.2017).

Tiger V., William Golding: The Dark Fields of Discovery, London 1974.

37 B. Oldsey, S. Weintraub, op. cit., p. 84. 